\title{
STABILIZACYJNA ROLA POLITYKI PIENIĘŻNEJ W WARUNKACH UNII WALUTOWEJ
}

\section{WPROWADZENIE}

Przedmiotem rozważań podjętych w niniejszej pracy jest znaczenie polityki pieniężnej w procesie stabilizacji makroekonomicznej w unii walutowej. Przyjęta problematyka badawcza wydaje się szczególnie istotna w świetle wydarzeń współczesnego kryzysu finansowo-gospodarczego. W debacie na temat jego przyczyn oraz przebiegu formułowane są liczne opinie i zalecenia dotyczące celów polityki pieniężnej i jej skuteczności w stabilizowaniu nominalnej i realnej sfery gospodarki. W szczególności poruszane są dwie kwestie: rola banku centralnego w zapewnieniu stabilności finansowej oraz oddziaływanie polityki pieniężnej w sytuacji głębokiego załamania gospodarczego.

Podstawę rozważań na temat stabilizacyjnej funkcji polityki pieniężnej stanowią istniejące $\mathrm{w}$ literaturze przedmiotu prace teoretyczne dotyczące polityki stabilizacji. Procesy integracji walutowej powoduja jednak, że wnioski wynikające $\mathrm{z}$ tych prac nie mogą być w prosty sposób zastosowane do analizy sytuacji gospodarczej całego ugrupowania oraz poszczególnych krajów członkowskich. W unii walutowej ponadnarodowy bank centralny prowadzi jednolitą politykę pieniężna dla wszystkich gospodarek członkowskich, które - pomimo wielu cech wspólnych - sa dość zróżnicowane pod względem istniejących w nich uwarunkowań ogólnogospodarczych. Konsekwencją nieoptymalnej, z punktu widzenia niektórych krajów członkowskich, polityki pieniężnej może być konieczność zaakceptowania przez nie niższego poziomu stabilizacji. Celem artykułu jest określenie możliwości wykorzystania jednolitej polityki pieniężnej w kształtowaniu stabilności makroekonomicznej na obszarze wspólnej waluty.

W pierwszej części pracy przedstawiono cele polityki stabilizacji oraz znaczenie polityki pieniężnej w ich osiąganiu, a także specyfikę prowadzenia jednolitej polityki pieniężnej w warunkach unii walutowej. Następnie zaprezentowano czynniki determinujące efektywność jednolitej polityki pieniężnej w procesie stabilizacji makroekonomicznej na obszarze wspólnej waluty. Ostatnią część pracy stanowi podsumowanie, w którym sformułowano najważniejsze wnioski wynikające z przeprowadzonych analiz o charakterze teoretycznym. 


\section{POLITYKA PIENIĘŻNA JAKO ELEMENT POLITYKI STABILIZACJI}

W literaturze ekonomicznej nie istnieje powszechnie stosowana, jednolita definicja polityki stabilizacji. Najczęściej jest ona definiowana przez pryzmat celów, których osiaganiu mają służyć odpowiednie działania podejmowane w ramach interwencjonizmu państwowego. Na przykład Tadeusz Kowalski określa politykę stabilizacji jako przedsięwzięcia podejmowane za pośrednictwem instrumentów polityki pieniężnej i fiskalnej w celu przeciwdziałania lub łagodzenia fluktuacji aktywności gospodarczej ${ }^{1}$. Uważa on, że zadaniem polityki stabilizacji jest utrzymywanie gospodarki jak najbliżej stanu pełnego zatrudnienia przy niskiej bądź zerowej inflacji bez pogarszania się bilansu płatniczego. W nieco odmienny sposób politykę stabilizacji ujmuja Ryszard Barczyk i Zygmunt Kowalczyk. Zgodnie z zaproponowana przez nich definicja politykę stabilizacji należy rozumieć jako ogół działań zmierzających do tworzenia i utrzymania równowagi ogólnogospodarczej, tj. równowagi wewnętrznej i zewnętrznej ${ }^{2}$. Pojęcie równowagi wewnętrznej odnoszone jest do sytuacji, w której w ramach systemu rynkowego osiagnięto: stabilne i wysokie tempo wzrostu gospodarczego, wysoki poziom zatrudnienia oraz stabilność cen. Równowaga zewnętrzna jest natomiast utożsamiania $\mathrm{z}$ równowaga $\mathrm{w}$ kontaktach gospodarczych z zagranicą ${ }^{3}$. Przedstawione warunki równowagi ogólnogospodarczej określa się w literaturze przedmiotu mianem tzw. czworokąta celów polityki stabilizacji ${ }^{4}$.

O ile wśród ekonomistów istnieje zgoda co do stwierdzenia, że polityka stabilizacji służy realizacji celów krótko- i średniookresowych, o tyle kwestią otwarta pozostaja kryteria oceny stopnia ich realizacji. Proponowane przez różnych autorów interpretacje poszczególnych celów polityki stabilizacji są zazwyczaj formułowane w sposób ogólny ${ }^{5}$. Konkretyzacji niektórych celów polityki stabilizacji dokonuje się na etapie opracowywania programów polityki gospodarczej, dostosowanych do aktualnej i prognozowanej sytuacji ekonomicznej kraju. Czworokąt celów należałoby raczej postrzegać nie jako zestaw celów samych w sobie, ale jako cechy stanu optymalnego, wyznaczające kierunki działań prowadzonych $\mathrm{w}$ ramach polityki stabilizacji.

1 T. Kowalski, Nowa klasyczna makroekonomia a polityka stabilizacji gospodarczej w kapitalizmie, „Ruch Prawniczy, Ekonomiczny i Socjologiczny” 1987, z. 2, s. 173.

${ }^{2}$ R. Barczyk, Z. Kowalczyk, Polityka stabilizacji koniunktury gospodarczej, Wyd. AE w Poznaniu, Poznań 1994, s. 15-16.

${ }^{3}$ R. Barczyk, Teoria i praktyka polityki antycyklicznej, Wyd. AE w Poznaniu, Poznań 2004, s. $16-17$ i 20.

${ }^{4}$ J. Pätzold, Stabilisierungspolitik: Grundlagen der nachfrage- und angebotsorientierten Wirtschaftspolitik, Paul Haupt Verlag, Bern-Stuttgart 1991, s. 18.

${ }^{5}$ Powszechnie przyjmuje się, że stabilny wzrost gospodarczy ma miejsce, kiedy dodatnia długookresowa tendencja ogólna produkcji dominuje nad jej wahaniami krótkookresowymi. Wysoki poziom zatrudnienia należy rozumieć jako możliwie niskie bezrobocie. Stabilność poziomu cen utożsamia się zazwyczaj z niską i stałą stopa inflacji, która zapewnia stabilną siłę nabywczą pieniądza. Równowaga zewnętrzna oznacza sytuację, w której nadwyżka lub deficyt w bilansie obrotów bieżących danej gospodarki nie wywołuje zakłóceń w jej równowadze wewnętrznej. 
Należy zaznaczyć, że omawiana koncepcja czworokata celów nie wyczerpuje wszystkich obszarów gospodarki wymagających interwencji w ramach prowadzonej polityki stabilizacji. W następstwie wydarzeń kryzysu finansowo-gospodarczego $2007+$, zdaniem wielu autorów, ochrona przed utrata stabilności finansowej powinna stanowić kolejny cel państwowej ingerencji w mechanizm rynkowy. Stabilność finansowa odnoszona jest do sytuacji, w której działalność gospodarcza nie jest zakłócana ani przez zmiany cen aktywów, ani trudności instytucji finansowych w zakresie wywiązywania się ze zobowiazań6.

Stabilność finansowa jest ściśle powiązana $\mathrm{z}$ realizacją podstawowych celów polityki stabilizacji. Podczas gdy w długim okresie cele te są wzajemnie komplementarne, to w krótkim okresie, stabilna sytuacja gospodarcza

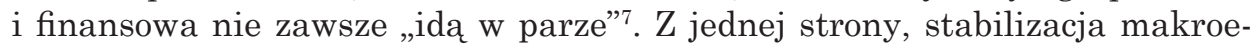
konomiczna rozumiana jako „zdrowe podstawy ogólnogospodarcze”, stanowi warunek stabilności całego systemu finansowego, ponieważ w znacznym stopniu zmniejsza jego wrażliwość na szoki i ułatwia dążenie do poprawy sytuacji na rynku finansowym w razie ewentualnych zaburzeń ${ }^{8}$. Należy jednak zaznaczyć, że okresom stabilizacji gospodarczej towarzyszą zazwyczaj niskie nominalne stopy procentowe, które mogą zachęcać do podejmowania dodatkowego ryzyka w celu osiagania wyższych nominalnych stóp zwrotu. Prowadzi to do kumulowania się w gospodarce, w szczególności w systemie finansowym, nadmiernego ryzyka, które może się zmaterializować, gdy ogólny stan gospodarki się pogorszy9 ${ }^{9}$. Stabilizacja makroekonomiczna jest zatem warunkiem koniecznym, choć nie wystarczającym zapewnienia stabilności finansowej. Z drugiej strony - stabilność finansowa jest niezbędnym warunkiem realizacji czworokąta celów. Jednakże samo jej zapewnienie nie stanowi gwarancji osiagnięcia podstawowych celów polityki stabilizacji w sposób automatyczny. Utrzymanie stabilności finansowej względem stabilizacji makroekonomicznej należy zatem również uznać za warunek konieczny, aczkolwiek nie wystarczający.

Niezależnie od przyjmowanej koncepcji celów polityki stabilizacji realizacja procesu stabilizacji makroekonomicznej w praktyce jest utrudniona, przede wszystkim z dwóch powodów:

- cele polityki stabilizacji sa wzajemnie powiązane, przy czym niektóre relacje maja charakter tzw. trade off (,,coś za coś”);

- polityka stabilizacji jest pewnego rodzaju konglomeratem różnych rodzajów polityki gospodarczej.

${ }^{6}$ A. Crockett, The Theory and Practice of Financial Stability, „De Economist” 144, 1996, $\mathrm{nr}$ 4, s. 532. Ponieważ stabilności finansowej nie można kontrolować poprzez obserwację jednego wskaźnika makroekonomicznego, w literaturze przedmiotu zwraca się uwagę na trudności w realizacji i ocenie zadania utrzymania stabilności finansowej. H. Żywiecka, Stabilność finansowa jako cel banku centralnego, „Bezpieczny Bank” 2012, nr 3, s. 70.

${ }^{7}$ M. Jurek, P. Marszałek, Pieniqdz, polityka pieniężna i systemy kursowe. Wspótczesne teorie i rozwiazania praktyczne, Wyd. AE w Poznaniu, Poznań 2007, s. 17.

${ }^{8}$ M. Kiedrowska, P. Marszałek, Stabilność finansowa-pojęcie, cechy $i$ sposoby jej zapewnienia, cz. I, „Bank i Kredyt” 2002, nr 4, s. 24.

${ }^{9}$ Z. Hockuba, Stabilność finansowa a stabilność cen, odczyt na Walnym Zgromadzeniu Związku Banków Polskich, Warszawa 2008, http://www.nbp.pl/publikacje/wyklady/hockuba_zbp.pdf (dostęp: 2.05.2013). 
Zjawisko trade off powoduje, że osiagnięcie jednocześnie wszystkich celów polityki stabilizacji jest niemożliwe ${ }^{10}$. Realizacja jednego z celów powoduje bowiem powstanie kosztu alternatywnego, którym jest odejście od stanu pożądanego w zakresie realizacji innego celu. Na przykład większe tempo wzrostu gospodarczego może, co prawda, przyczynić się do wzrostu zatrudnienia, ale jednocześnie spowoduje zwiększenie tendencji inflacyjnych oraz pogorszenie się bilansu płatniczego ${ }^{11}$. Ponadto proces stabilizacji makroekonomicznej wymaga wykorzystania różnorodnych instrumentów polityki gospodarczej, co de facto oznacza, że polityka stabilizacji jest zestawem narzędzi z zakresu polityki fiskalnej, dochodowej, pieniężnej oraz kursowej, a także, na co zwraca uwage m.in. Andrzej Sławiński, polityki nadzorczej ${ }^{12}$. Pojawia się zatem problem związany z koordynacja decyzji podejmowanych przez różne instytucje odpowiedzialne za konkretny obszar interwencjonizmu państwa. Każdy z wymienionych rodzajów polityki ma właściwe dla siebie cele nadrzędne, które w sposób bezpośredni można odnieść do poszczególnych celów polityki stabilizacji ${ }^{13}$. Osiaganie celów nadrzędnych poszczególnych rodzajów polityki gospodarczej może, w sposób pośredni, sprzyjać bądź nie (zgodnie ze zjawiskiem trade off) osiaganiu pozostałych celów polityki stabilizacji. Problem koordynacji decyzji w ramach polityki stabilizacji należy zatem widzieć również w kontekście hierarchii ważności realizowanych przez nią zadań.

Od lat dziewięćdziesiątych ubiegłego wieku podstawę teoretyczną prowadzenia polityki pieniężnej stanowi nowa synteza neoklasyczna. W ramach tego nurtu przyjmuje się, że z punktu widzenia polityki pieniężnej cel inflacyjny jest priorytetowy, tzn. może ona wspierać osiaganie pozostałych celów polityki stabilizacji, jednakże w stopniu, który nie zakłóca osiagnięcia jej celu podstawowego. Po kryzysie zapoczątkowanym w 2007 r. rozpoczęła się debata nad przypisaniem bankowi centralnemu dodatkowego zadania: zapewnianie stabilności finansowej. Rozważania te zastapiły standardową dyskusję o możliwościach wpływania przez bank centralny na realną sferę gospodarki. Obecnie, po nasileniu zaburzeń w sferze finansowej i załamaniu gospodarczym, wsparcie stabilności finansowej przez bank centralny obok dbałości o stabilność cen w ramach elastycznej strategii celu inflacyjnego wydaje się przesądzone ${ }^{14}$. Podstawowym instrumentom służącym stabilności finansowej-

${ }_{10}$ Warto nadmienić, że z tego powodu w literaturze przedmiotu czworokąt celów polityki stabilizacji określa się często jako „magiczny”. Przymiotnik ten stosuje m.in. J. Pätzold, op. cit., s. 18.

11 J. Misala, Stabilizacja makroekonomiczna $w$ Polsce $w$ okresie transformacji ze szczególnym uwzględnieniem deficytów bliźniaczych, Instytut Gospodarki Światowej, Warszawa 2007, s. 11.

12 A. Sławiński, Makroekonomia a nadzór bankowy, „Rzeczpospolita” z 16 marzec 2010 r., http://www.rp.pl/artykul/19423,447653_Makroekonomia_a_nadzor_bankowy.html (dostęp: 10.09.2013).

${ }_{13}$ W. Przybylska-Kapuścińska, Istota i cele polityki pieniężnej, w: eadem (red.), Wspótczesna polityka pieniężna, Difin, Warszawa 2008, s. 34.

${ }_{14}$ M. Szyszko, Wptyw banków centralnych na sferę realna we wspótczesnej gospodarce, w: W. L. Jaworski, A. Szelagowska (red.), Wspótczesna bankowość centralna, CeDeWu, Warszawa, 2012, s. 186. Szerzej na ten temat: M. Szyszko, Współczesna teoria ekonomii a polityka pieniężna, w: W. Przybylska-Kapuścińska, M. Szyszko (red.), Wyzwania współczesnej polityki pieniężnej, Difin, Warszawa 2012, s. 13-25; W. Przybylska-Kapuścińska, M. Szyszko, Ewolucja nowoczesnych strategii polityki pieniężnej, w: eaedem (red.), op. cit., s. 26-36. 
regulacjom rynku finansowego towarzyszyć ma aktywna postawa banku centralnego w momentach nasilania się nierównowagi w systemie finansowym. Rolę instrumentu wspomagajacego działanie narzędzi wpisanych w ramy polityki nadzorczej może pełnić stopa procentowa. Przypisuje się jej jednak wyłącznie funkcję pomocnicza, ponieważ jej podniesienie do poziomu wystarczająco wysokiego, by działanie to miało istotny wpływ na ceny aktywów i dynamikę kredytów, miałoby silny negatywny wpływ na pozostałe ze stabilizacyjnych celów ${ }^{15}$. Ponadto ze względu na potwierdzony w badaniach empirycznych związek pomiędzy narastaniem bańki na rynku aktywów finansowych a poprzedzającym to zjawisko wzrostem akcji kredytowej i podaży pieniądza na rynku zaleca się obserwacje obu tych zmiennych ${ }^{16}$. Pomimo pewnych propozycji dotyczących sposobu koordynacji polityki pieniężnej i nadzorczej zagadnienie to pozostaje nadal nierozwiązane w toczącej się obecnie debacie.

Kryzys 2007+ ujawnił - w skali globalnej - nieskuteczność standardowego instrumentarium polityki pieniężnej. Odzwierciedleniem tego był brak oczekiwanych efektów silnych obniżek stóp procentowych - poprawy płynności na rynku międzybankowym i zwiększenia aktywności kredytowej banków komercyjnych. W obliczu nieskuteczności tradycyjnych instrumentów polityki pieniężnej banki centralne zostały zmuszone do poluzowania dotychczas stosowanych rozwiązań w polityce pieniężnej przez zastosowanie quantitative i qualitative easing, czyli tzw. niestandardowych narzędzi w polityce pieniężnej ${ }^{17}$. W obliczu ograniczonej skuteczności polityki pieniężnej w większości krajów na świecie wprowadzono fiskalne pakiety stymulacyjne o znacznej skali, co w dużym stopniu przyczyniło się do odwrócenia skutków kryzysu. Wydarzeniom tym towarzyszyła wyraźna zmiana w ocenie efektywności polityki pieniężnej i fiskalnej w pokryzysowej stabilizacji ${ }^{18}$. Kwestia skuteczności polityki pieniężnej w osiaganiu celów stabilizacyjnych wymaga ponownej, pogłębionej analizy także w kontekście uczestnictwa danej gospodarki w procesach integracji walutowej.

Tradycyjnie przyjmuje się, że organy publiczne działają w ramach państw narodowych i nie odczuwają ograniczeń zewnętrznych w określaniu celów i narzędzi korygowania mechanizmu rynkowego. W opinii autora tych słów -

\footnotetext{
${ }^{15}$ W. Przybylska-Kapuścińska, M. Szyszko, Ewolucja nowoczesnych strategii polityki pienięż$n e j$, w: eaedem (red.), op. cit., s. 29-30.

${ }^{16}$ C. Borio, P. Lowe, Securing Sustainable Price Stability: Should Credit Come Back from the Wilderness?, BIS Working paper, No. 157, 2004; O. Issing, Assets Prices and Monetary Policy, „Cato Journal” 29, 2009, nr 1.

${ }^{17}$ W. Przbylska-Kapuścińska, Krytyka celów i instrumentów kreowania polityki pieniężnej współczesnych banków centralnych, w: W. L. Jaworski, A. Szelagowska (red.), Wspótczesna bankowość centralna, CeDeWu, Warszawa 2012, s. 36. Opracowanie nie będzie zawierało analizy nadzwyczajnych programów wspierania płynności. Szerzej na ten temat: H. Kołodziejczyk, Działania Systemu Rezerwy Federalnej i Europejskiego Banku Centralnego w reakcji na kryzys finansowy, w: W. Przybylska-Kapuścińska, M. Szyszko (red.), op. cit., s. 84-103.

${ }^{18}$ M. Gajda-Kantorowska, Analiza przydatności polityki fiskalnej do usuwania skutków kryzysu w krótkim, średnim i długim okresie, w: Z. Dach (red.), Polityka makroekonomiczna w warunkach kryzysu i jej wptyw na gospodarkę. Teoria i praktyka, Wolters Kluwer, Warszawa 2011, s. 115 .
} 
Adama Lipowskiego wynika to z ignorowania politycznych następstw istnienia w gospodarce światowej współzależności, których przyczyną są dwa procesy: integrowanie się rynków krajowych oraz rozwój struktur ponadnarodowych ${ }^{19}$. Zdaniem Jerzego Wosia i Anny Hnatyszyn-Dzikowskiej, te zmieniające się uwarunkowania gospodarcze determinuja możliwości stabilizacyjnego oddziaływania zarówno władz monetarnych, jak i rządu i powoduja że formuła interwencjonizmu państwowego nie może być stała ${ }^{20}$.

Willem Molle definiuje integrację gospodarczą jako „stopniową eliminację granic ekonomicznych między niepodległymi państwami, w wyniku czego gospodarki tych państw zaczynają funkcjonować jako jedna całość”ㄹ. Uważa on, że na integrację gospodarczą składa się integracja rynków (dóbr i usług oraz czynników produkcji) oraz integracja różnych obszarów polityki. Oba te procesy następują stopniowo - przechodzac przez kolejne, coraz bardziej zaawansowane etapy integracji gospodarczej. Wzorując się na klasyfikacjach zaproponowanych przez Bélę Balassę oraz Pawła Bożyka i Józefa Misalę przyjęto, że proces integracji gospodarczej obejmuje następujące etapy: strefę wolnego handlu, unię celna, wspólny rynek, unię walutowa, unię gospodarczą oraz unię polityczna ${ }^{22}$.

Przechodzeniu do kolejnych stadiów integracji nie towarzyszy zmiana samego pojęcia polityki stabilizacji - jej cele pozostają te same. Zmienia się jednak instytucjonalny system interwencjonizmu państwowego w zakresie tej polityki. W przypadku pierwszych trzech etapów system ten tworzą wyłącznie instytucje narodowe, a zatem kraje członkowskie posiadaja pełną swobodę w kształtowaniu własnej polityki stabilizacji. Kolejne trzy etapy wiąża się natomiast z koniecznością delegowania lub koordynowania zadań, które dotychczas były realizowane wyłącznie przez organy narodowe - instytucjom ponadnarodowym funkcjonujacym w ramach danego ugrupowania ${ }^{23}$.

W unii walutowej „dwupoziomowa” realizacja procesu stabilizacji makroekonomicznej polega na tym, że na szczeblu ponadnarodowym działa wspólny

19 A. Lipowski, Mała gospodarka otwierajaca się wobec wyzwań XXI w. - ku realistycznym podstawom polityki gospodarczej, „Ekonomista” 2003, nr 3, s. 277-278.

${ }^{20}$ J. Woś, A. Hnatyszyn-Dzikowska, Stabilizacyjna funkcja państwa $w$ teoriach wspótczesnych szkót ekonomicznych, „Ruch Prawniczy, Ekonomiczny i Socjologiczny” 2006, z. 4, s. 109.

${ }_{21}$ W. Molle, Ekonomika integracji europejskiej. Teoria, praktyka, polityka, Fundacja Gospodarcza, Gdańsk 2000, s. 8-9 i 11. W literaturze przedmiotu nie wypracowano jednej, powszechnie stosowanej definicji integracji gospodarczej. Jak zauważa S. I. Bukowski, jest to związane z tym, że procesy integracyjne są skomplikowane, a ponadto ich wymiar ekonomiczny jest ściśle powiazany z wymiarem politycznym. Autor ten przedstawia przegląd różnych definicji pojęcia integracji gospodarczej - zob. S. I. Bukowski, Unia monetarna. Teoria i praktyka, Difin, Warszawa 2007, s. 13-18.

${ }^{22}$ B. Balassa, The Theory of Economic Integration, Richard D. Irwin, Homewood 1961, s. 1-2; P. Bożyk, J. Misala, Integracja ekonomiczna, PWE, Warszawa 2003, s. 38. Przyjmowana przez poszczególnych autorów typologia etapów integracji gospodarczej różni się zarówno pod względem liczby wyodrębnianych etapów, ich nazewnictwa, jak i charakterystyki. Por. np.: A. Budnikowski, Międzynarodowe stosunki gospodarcze, PWE, Warszawa 2001, s. 246-250; E. Jantoń-Drozdowska, Międzynarodowe stosunki gospodarcze, Ars boni et aequi, Poznań 2009, s. 210 i 212; J. Rymarczyk, Międzynarodowe stosunki gospodarcze, PWE, Warszawa 2010, s. 295-296.

${ }^{23}$ Im wyższy stopień zaawansowania procesów integracyjnych, tym więcej obszarów polityki stabilizacji przenoszonych jest na szczebel ponadnarodowy. 
bank centralny, który prowadząc jednolitą politykę pieniężną dąży do osiąnięcia celu/-ów na poziomie całego ugrupowania, natomiast na szczeblu krajowym funkcjonują rządy poszczególnych państw członkowskich, w których interesie leży realizacja zadań stabilizacyjnych na poziomie własnych gospodarek. Wywołana procesem integracji walutowej zmiana instytucjonalnego systemu interwencjonizmu państwowego w zakresie polityki stabilizacji wpływa na osiagane cele. Po pierwsze, zadania mające doprowadzić do ich osiagnięcia sa realizowane na różnych szczeblach władzy: na szczeblu ponadnarodowym oraz państwowym. Po drugie, ich osiagnięcie można odnieść do dwóch poziomów: do całego ugrupowania oraz do poszczególnych gospodarek w nim uczestniczących. Ponieważ stan koniunktury gospodarczej ugrupowania jako całości ocenia się na podstawie uśrednionych wskaźników makroekonomicznych, więc osiagnięcie celów stabilizacyjnych we wszystkich krajach członkowskich oznaczałoby ex definitione ich automatyczne osiąnięcie na poziomie ugrupowania. Odwrotna zależność nie jest już tak oczywista: osiagnięcie stabilizacyjnych celów w ramach całego ugrupowania nie przekłada się automatycznie na wszystkie kraje członkowskie. Uśrednione dane mogą bowiem „maskować” znaczne zróżnicowanie w kształtowaniu się głównych wskaźników makroekonomicznych w poszczególnych gospodarkach.

\section{DETERMINANTY EFEKTYWNOŚCI JEDNOLITEJ POLITYKI PIENIĘŻNEJ W PROCESIE STABILIZACJI MAKROEKONOMICZNEJ}

Na podstawie literatury ekonomicznej można sformułować listę tzw. warunków wstępnych, których spełnienie, przynajmniej w założeniach, gwarantuje osiaganie korzyści z tytułu jednolitej polityki pieniężnej ${ }^{24}$. Należy jednak zaznaczyć, że pełna realizacja tych założeń w poszczególnych państwach członkowskich jest niemożliwa. W rzeczywistości gospodarczej do strefy jednolitej waluty przystępują kraje w znacznym stopniu różniące się pod względem panujacych w nich warunków mikro- i makroekonomicznych. Te szczególne uwarunkowania powoduja, że w analizie dotyczącej stabilizacyjnego oddziaływania jednolitej polityki pieniężnej w unii walutowej należy uwzględnić przede wszystkim:

- ryzyko nieadekwatności jednolitej polityki pieniężnej,

- jakość krajowej polityki fiskalnej,

- zagrożenie nieadekwatności polityki nadzorczej.

Ponieważ siła i kierunek działań podejmowanych w ramach jednolitej polityki pieniężnej zależą od oceny sytuacji gospodarczej całego ugrupowania, ich wpływ na stabilizację makroekonomiczną poszczególnych krajów członkow-

${ }^{24}$ Szerzej na temat warunków optymalnego obszaru walutowego zob. np.: M. Misiak, Polityka stabilizacyjna $w$ wieloszczeblowym systemie sprawowania wtadzy. Przyktad Unii Gospodarczo-Walutowej $w$ dobie kryzysu gospodarczo-finansowego, Centrum Europejskie Natolin, Warszawa 2013, s. 10-21. 
skich może być zróżnicowany. Realizacja założonych celów wspólnej polityki pieniężnej może być „zakłócona” m.in. przez zróżnicowanie poziomu rozwoju gospodarczego w ramach ugrupowania oraz niski stopień synchronizacji cykli koniunkturalnych krajów członkowskich unii walutowej. Co więcej, czynniki te mogą wzmacniać lub osłabiać efekty jednolitej polityki pieniężnej w poszczególnych krajach członkowskich i doprowadzić nawet do destabilizacji ich sytuacji gospodarczej. W rozważaniach dotyczących integracji walutowej oraz skuteczności działań podejmowanych przez ponadnarodowy bank centralny określa się to mianem ryzyka nieadekwatności jednolitej polityki pieniężnej o charakterze strukturalnym i cyklicznym.

Kraje znajdujące się na wyższym (niższym) poziomie rozwoju gospodarczego odnotowują niższe (wyższe) tempo wzrostu gospodarczego i cen, niższy (wyższy) spadek bezrobocia oraz mniejszą (większa) nierównowagę zewnętrzną niż średnie wartości wymienionych wskaźników rejestrowane na poziomie unii walutowej. Z uwagi na fakt, że jednolita polityka pieniężna jest kształtowana na podstawie sytuacji gospodarczej całego ugrupowania, przyjęte założenie implikuje, że w krajach znacznie różniących się poziomem rozwoju gospodarczego na tle ugrupowania polityka ta może ostatecznie mieć charakter procykliczny, a nie stabilizujacy. Procykliczne oddziaływanie jednolitej polityki pieniężnej może mieć również miejsce $\mathrm{w}$ gospodarkach, które cechuje niski stopień synchronizacji cyklu koniunkturalnego z cyklem ugrupowania.

Istota problemu strukturalnej i cyklicznej nieadekwatności jednolitej polityki pieniężnej polega na tym, że scentralizowana polityka pieniężna efektywna na poziomie całego obszaru walutowego - nie musi być optymalna z punktu widzenia stabilizacyjnych potrzeb poszczególnych jej krajów członkowskich $^{25}$.

Zróżnicowana reakcja na impulsy jednolitej polityki pieniężnej powodowana zjawiskiem nieadekwatności jednolitej polityki pieniężnej w poszczególnych krajach członkowskich może być utożsamiana ze skutkami wystapienia w nich wstrząu o charakterze asymetrycznym. Bez względu na faktyczne źródło jego zaistnienia, antidotum na jego złagodzenie powinny, zgodnie z teorią, stanowić sprawnie działające mechanizmy dostosowawcze, tj.: elastycznie

${ }^{25}$ Problem asymetrycznego oddziaływania scentralizowanej polityki pieniężnej w unii walutowej poruszył już w roku 1977 H. G. Grubel. Zob. idem, International Economics, Homewood, Illinois 1977, s. 452. Na ten temat zob. również: A. Sławiński, Znaczenie czynników ryzyka towarzyszacych wchodzeniu Polski do ERM2 i do strefy euro, „Ekonomista” 2008, nr 1, s. 33-50; C. Wójcik, Integracja ze strefa euro. Teoretyczne i praktyczne aspekty konwergencji, WN PWN, Warszawa 2008; A. Rogut, Koszty i zagrożenia zwiazane $z$ wejściem Polski do strefy euro, w: P. Kowalewski et al. (red.), Mechanizmy funkcjonowania strefy euro, NBP, Warszawa 2010, s. 191-210; M. Ochrymiuk, A. Rogut, Konwergencja nominalna w strefie euro. Implikacje dla Polski, Narodowy Bank Polski, Warszawa 2010, s. 36-37; Z. Urbanowicz, Wptyw polityki pieniężnej Europejskiego Banku Centralnego na stabilność sfery realnej $w$ strefie euro, „Studia i Prace Wydziału Nauk Ekonomicznych i Zarządzania Uniwersytetu Szczecińskiego” 2014 [w druku]; Z. Urbanowicz, Wptyw polityki pieniężnej Europejskiego Banku Centralnego na stabilność cen w strefie euro, „Prace Naukowe Uniwersytetu Ekonomicznego we Wrocławiu” 2014 [w druku]. Przegląd empirycznych pomiarów zjawiska nieadekwatności jednolitej polityki pieniężnej w strefie euro zawiera praca: Z. Urbanowicz, Inadequacy of the European Central Bank's Monetary Policy in the Process of Macroeconomic Stabilization in the Eurozone, UEP, maszynopis powielony, 2014. 
obniżajace się płace redukujące koszty produkcji i ceny, swobodny przepływ siły roboczej obniżajacy rozmiary bezrobocia, przepływ kapitału dla zachowania jego efektywności krańcowej, transfery fiskalne ze zcentralizowanego budżetu federalnego, narodowa polityka fiskalna ${ }^{26}$. Tej ostatniej przypisuje się największą rolę w akomodowaniu negatywnych wstrzassów asymetrycznych.

Możliwości wykorzystania instrumentów polityki fiskalnej do łagodzenia wahań aktywności gospodarczej zależą w dużym stopniu od kondycji finansów publicznych. Ich korzystny stan jest warunkowany konsekwentnym prowadzeniem symetrycznej polityki budżetowej. Oznacza to konieczność antycyklicznego zacieśniania fiskalnego w czasach ożywienia gospodarczego celem stworzenia przestrzeni fiskalnej dla działań dyskrecjonalnych w czasach dekoniunktury ${ }^{27}$. W krajach unii walutowej, w których nie prowadzi się zdyscyplinowanej i przejrzystej polityki fiskalnej, decyzja dotyczaca rezygnacji z autonomicznej polityki pieniężnej może okazać się wyjątkowo nierozważna, a straty w zakresie ich stabilizacji makroekonomicznej dotkliwe ${ }^{28}$.

Zbyt ekspansywna polityka budżetowa nie tylko ogranicza możliwości wykorzystania jej instrumentów do celów stabilizacyjnych, ale także może stać się źródłem niestabilności makroekonomicznej na poziomie krajowym i ponadnarodowym ${ }^{29}$. Z tego powodu w literaturze przedmiotu postuluje się konieczność wprowadzenia dodatkowego systemu kontroli finansów publicznych w krajach członkowskich w roli zarówno „strażnika”, jak i „egzekutora” dyscypliny budżetowej ${ }^{30}$.

Problemem dyskutowanym w literaturze przedmiotu jest instytucjonalny kształt polityki nadzorczej nad jednolitym rynkiem finansowym unii walutowej. W rozważaniach dotyczących tego zagadnienia dominuje podejście zakładające częściową centralizację tej polityki, tzn. utworzenie systemu nadzoru opartego na współpracy ponadnarodowego banku centralnego oraz organów nadzorczych na szczeblu unijnym i krajowym. Wątpliwości ekonomistów doty-

${ }^{26}$ Krytyczna ocena funkcjonowania wymienionych mechanizmów dostosowawczych w odniesieniu do współczesnej praktyki gospodarczej zob. W. Jakóbik, Dylematy akcesji do strefy euro, w: J. Stacewicz (red.), Polityka gospodarcza w świetle kryzysowych doświadczeń, SGH, Warszawa, 2011, s. $117-144$.

${ }_{27}$ M. Jurek, Ograniczenie autonomii polityki pieniężnej w warunkach integracji finansowej, „Ekonomista” 2010, nr 3, s. 340.

${ }_{28}$ B. Eichengreen, J. von Hagen, Fiscal Policy and Monetary Union: Federalism, Fiscal Restrictions and the No-bailout Rule, „CEPR Discussion Papers” 1995, nr 1247; P. De Grauwe, Unia walutowa. Funkcjonowanie i wyzwania, PWE, Warszawa 2003.

${ }^{29}$ Szerzej na ten temat zob. D. Rosati, Kierunki zmian w systemie zarzadzania fiskalnego w strefie euro, „Ekonomista” 2010, nr 5, s. 609-645.

${ }^{30}$ P. de Grauwe, Y. Ji, How Much Fiscal Discipline in a Monetary Union?, „Journal of Macroeconomics” nr 39, 2014, s. 250-259. Szerzej na ten temat w odniesieniu do strefy euro zob. K. Marchewka-Bartkowiak, Reformy Paktu na rzecz stabilności i wzrostu, „Studia BAS” 3, 2010, s. 141-160; eadem, Nowe ponadnarodowe reguty budzetowe odpowiedzia na kryzys zadtuzenia publicznego $w$ strefie euro, „Studia Ekonomiczne” 2012, nr 1, s. 51-72; eadem, Korzyści i koszty wejścia Polski do strefy euro w świetle integracji długu i budżetu UGW, w: J. Adamiec (red.), Wprowadzenie euro $w$ Polsce - za i przeciw, BAS, 2013, Warszawa; eadem, Obligacje unijne, „Infos BAS” 18, 2013, s. 1-4; G. Tchorek, Nierównowagi fiskalne i makroekonomiczne w strefie euro a nowe rozwiazania instytucjonalne, „Management and Business Administration. Central Europe" 21, 2013, nr 2 (121), s. 186-204. 
czą kwestii podziału kompetencji między wymienione instytucje, a w szczególności zakresu uprawnień ponadnarodowego banku centralnego w nadzorowaniu stabilności finansowej na jednolitym rynku finansowym. W konsekwencji wydarzeń kryzysu 2007+, także w warunkach unii walutowej, postuluje się zwiększenie roli ponadnarodowego banku centralnego w dbałości o stabilność finansowa. Istotna i nadal nierozstrzygnięta w literaturze przedmiotu pozostaje jednak kwestia techniczna zapewnienia stabilności na jednolitym rynku finansowym w warunkach scentralizowanej polityki pieniężnej i ryzyka jej nieadekwatności. Na przykład kraje o wyższej niż średnia naturalna stopa procentowa, dla których podstawowa stopa procentowa wspólnego banku centralnego będzie zbyt niska, mogą być narażone na większe ryzyko bańki spekulacyjnej na rynku aktywów. Jest to ważny argument przeciwko proponowanej harmonizacji regulacji makroostrożnościowych w Unii Europejskiej ${ }^{31}$.

\section{PODSUMOWANIE}

W unii walutowej prowadzona jest jednolita polityka pieniężna dla wszystkich krajów członkowskich, które pomimo wielu cech wspólnych, stanowią dość heterogeniczna grupę zarówno pod względem istniejących w nich uwarunkowań mikro-, jak i makroekonomicznych. O ile w literaturze przedmiotu można odnaleźć wiele publikacji, w których coraz większa synchronizacja cykli koniunkturalnych oraz proces konwergencji realnej (zmniejszenie różnic $\mathrm{w}$ poziomie PKB per capita) sa podawane jako jedne z konsekwencji przyjęcia wspólnej waluty, o tyle wyniki badań empirycznych nie dostarczaja jednoznacznego potwierdzenia dla tych poglądów. Rozbieżności o charakterze cyklicznym i strukturalnym moga powodować, że scentralizowana polityka pieniężna, efektywna na poziomie całego obszaru walutowego, nie musi być optymalna z punktu widzenia poszczególnych krajów członkowskich. Wydaje się zatem, że konsekwencją zróżnicowania gospodarek członków unii walutowej może być odmienna skuteczność jednolitej polityki pieniężnej w kształtowaniu ich stabilności makroekonomicznej. W tym kontekście warunkiem osiągania korzyści ze wspólnej polityki pieniężnej są: wysoka zbieżność ich cykli koniunkturalnych i zbliżony poziom rozwoju gospodarek członkowskich. Spełnienie tych warunków zwiększa prawdopodobieństwo skutecznego oddziaływania jednolitej polityki pieniężnej na proces stabilizacji makroekonomicznej zarówno na poziomie ugrupowania, jak i jego krajów członkowskich. Wpływ wspólnej polityki pieniężnej obserwowany na wyróżnionych poziomach będzie w tym przypadku zbliżony, zarówno co do siły, jak i kierunku działania.

W sytuacji nieadekwatnej polityki pieniężnej ciężar stabilizacji makroekonomicznej na poziomie krajów członkowskich spoczywa przede wszystkim na

${ }^{31}$ L. Balcerowicz, O zapobieganiu kryzysom w strefie euro, „Ruch Prawniczy, Ekonomiczny i Socjologiczny” 2013, z. 1, s. 152-154. Na ten temat zob. także: G. Tchorek, J. Czaja, Doświadczenia integracji rynków finansowych w strefie euro. Implikacje dla Polski, w: J. Adamiec (red.), op. cit., s. 93-95. 
polityce fiskalnej. Możliwości wykorzystania fiskalnych narzędzi do stabilizowania gospodarki zależą jednak w dużej mierze od kondycji finansów publicznych. W odpowiedzi na kryzys w strefie euro wprowadzono wiele nowych instrumentów mających wzmocnić dyscyplinę fiskalną na obszarze wspólnej waluty ${ }^{32}$. Krótko- i średniookresowe efekty tych działań oceniane sa obecnie „umiarkowanie pozytywnie” ${ }^{33}$. Trudno jednak przewidzieć, czy inicjatywy te okażą się wystarczające, aby istotnie obniżyć prawdopodobieństwo wystąpienia podobnego kryzysu w przyszłości. Ponadto zasadniczym warunkiem osiagania korzyści z oddziaływania polityki pieniężnej w procesie stabilizacji makroekonomicznej jest stabilność jednolitego rynku finansowego. O ile wśród ekonomistów istnieje ogólny konsens w sprawie nowego kształtu architektury nadzoru w strefie euro, o tyle wątpliwości może wzbudzać kwestia operacyjna proponowanych rozwiązań.

Analizowany problem badawczy jest szczególnie istotny z perspektywy polskiej gospodarki, która wraz z przystapieniem do Unii Europejskiej stała się członkiem z tzw. derogacją Unii Gospodarczej i Walutowej. Status kraju członkowskiego z derogacją oznacza, że Polska jest formalnie zobowiąana do przyjęcia wspólnej waluty euro i chociaż dokładny termin jej wprowadzenia nie został jeszcze określony, to będzie ona musiała stawić czoło konsekwencjom wynikającym z jednolitej polityki pieniężnej w kontekście jej stabilizacji makroekonomicznej.

dr Zuzanna Urbanowicz

Uniwersytet Ekonomiczny w Poznaniu

zuzanna.urbanowicz@ue.poznan.pl

\title{
A STABILISING ROLE OF THE MONETARY POLICY IN THE COMMON CURRENCY UNION
}

\author{
Sum mary
}

The aim of this article is to determine the influence of the single monetary policy on the process of macroeconomic stabilisation in the monetary union. The basis for the considerations concerning the impact of the monetary policy on the macroeconomic stabilisation process in the common currency area is theoretical works on the stabilisation policy existing in the related literature. However, the monetary integration processes are responsible for the fact that the conclusions of these works cannot be easily applied to the analysis of the economic situation in the entire currency union and in its individual member states. In the monetary union, the main central bank conducts the single monetary policy for all member states which, despite many common features, are quite a heterogeneous group at the micro- as well as the macro level. These special characteristics are the reason for which the analysis of the stabilising influence of the single monetary policy in the monetary union should include a risk of inadequacy of the single monetary policy, the quality of national fiscal policy, as well as the risk of inadequacy of supervisory policy.

${ }^{32}$ Szczegółowa analiza stabilizacyjnych działań w odniesieniu do kryzysu finansów publicznych 2009+ znajduje się w: P. Albiński (red.), Kryzys a polityka stabilizacyjna w Unii Europejskiej, SGH, Warszawa 2013.

${ }^{33}$ Ibidem, s. 245. 
Copyright of Journal of Law, Economics and Sociology is the property of Faculty of Law and Administration of Adam Mickiewicz University in Poznan and its content may not be copied or emailed to multiple sites or posted to a listserv without the copyright holder's express written permission. However, users may print, download, or email articles for individual use.

Właścicielem praw autorskich do „Ruchu Prawniczego, Ekonomicznego i Socjologicznego” jest Wydział Prawa i Administracji Uniwersytetu im. Adama Mickiewicza w Poznaniu. Zawartość czasopisma nie może być kopiowana, przesyłana do innych stron internetowych bądź zamieszczana na blogach bez pisemnej zgody wydawcy. Niemniej artykuły można drukować, kopiować lub przesyłać w formie elektronicznej na własny użytek. 